\title{
DNA Repair Protein REV1
}

National Cancer Institute

\section{Source}

National Cancer Institute. DNA Repair Protein REV1. NCI Thesaurus. Code C106285.

DNA repair protein REV1 (1251 aa, $138 \mathrm{kDa}$ ) is encoded by the human REV1 gene. This protein plays a role in translesion DNA synthesis. 